\title{
E-books: A Paradigm Shift and Legal Issues
}

\author{
Lalitha Aswath ${ }^{1}$ \\ N.M. Anjaneya Reddy ${ }^{2 *}$
}

\begin{abstract}
In the digital era, the publication industry talks more about e-books utility across the world. But in the Indian scenario, usage of e-books is predominantly low compared with other developed countries. The publisher's strategies like control over e-books platform, licencing and other legal issues are pushing back libraries from the procurement of e-books. This article makes a modest attempt to describe the conceptual framework, advantages, disadvantages, usage, legal issues, access models and licencing pertaining to e-books procurement.
\end{abstract}

Keywords: E-books, Digital books, E-books licencing, Copyright law, E-book module, E-book platform, E-book access models

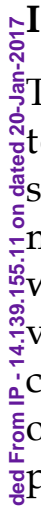

\section{INTRODUCTION}

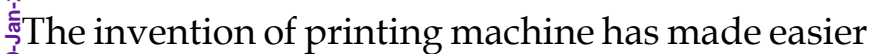
stto produce large number of printed books in ș shorter time. Before the invention of printing -machine that is prior to 1440 , the book had been Written by hand and the each copy had real work value. Later, research in the field of printing and communication has revolutionised the invention Eof technology which led to significant changes in oprinting industry. These inventions are led to 政derive the new tools for accessing variety of ônformation. Books and journals are replaced with its electronic forms called e-books and e-journals; e-book is a kind of book in an electronic format and can be accessed using computer technology. This has made easy to access e-books simultaneously by multiple readers in multiple location, but on the other hand, it is the toughest task for copyright holder to control the copyright violations.

Print books are active since the fifteenth century and still continue to occupy a prime place in libraries and continued to be so because of its demand, and readers have accustomed to the format for centuries.

\section{The Advantage of Printed Books}

1. Easier to read and doesn't affect on eyes

2. Doesn't require any other tool to read

3. Tangibility and credibility

4. Quick page turn

5. No technology required

Disadvantages of Printed Books;

1. Heavy to carry/not easy to carry everywhere

2. Occupies more physical space

3. Require light to read

4. Use by one at a time

\section{E-books: Conceptual Framework}

The history of e-book has begun during the Second World War with a device called Memex (Manley and Holley, 2012).

1945 - An American engineer and Professor Vannevar Bush imagined and developed a hypertext that a device would store, search and display data sources organised in a single device. He called that device as 'Memex'. It was an individual store for all his books and records, mechanised to search easily.

${ }^{1}$ Professor, ${ }^{2}$ Research Scholar, DLIS, Bangalore University, Bengaluru-560056, Karnataka, India

( ${ }^{*}$ Corresponding author) e-mail id: *areddy.ragini@gmail.com, ${ }^{1}$ drlalitha.aswath@gmail.com 
1960 - Bush's idea of electronic information processing system was later re-developed by Alan Kay with his researchers at Xerox's Palo Alto Research Center in the late 1960s, and he conceptualised notebook computer.

1971 - Technological inventions and ideas stimulated for Gutenberg project started by Michael S. Hart in the year 1971 for digitising books.

1986 - A 'dynamic book' was developed by William Morridge at Grid Computer Systems Corporation and manufactured by Toshiba in 1986.

1987 - The SuperBook software project started at Bell Communications Research, USA. The purpose of the project was to find new methods for ônavigating electronic books and proved for ङintegrating search results with navigations.

Throughout the 1970s, 1980s and 1990s, US cagencies and research centres such as Defence -Advanced Research Projects Agency (DARPA), Xerox PARC and National Science Foundation (NSF) have developed new technology and new network standards which led to the development oof communication media predominantly. Since othe 1990s, many e-book readers and other ghandheld devices were developed. The devices like S亏 Sony Data Discman, Sony Bookman, SoftBook reader, NuvoMedia's Rocket eBook Reader, EveryBook and many more readers are being developed.

2006 - Sony released portable Reader System PRS500; using E-Ink technology possible to connect with eBook store.

2007 - Kindle device released by Amazon.

2008 - E-book-wise reader released.

2009 - Kindle new versions, Cool-ER, Ditto Book, Sony Reader Touch, iPhone, iPod Touch, Sony Reader Daily Edition, Sony Reader Pocket, Irex Iliad and the Acer Netbook. Nook released by Barnes and Noble.

2010 - E-readers adopted by many libraries. Google launched eBooks project (Google Edition).
2011 - Kindle Customers were able to borrow ebooks from libraries - public libraries of USA started lending services to its users.

2012 - E-book and audio book lending records at many libraries.

In the recent past, the use of e-books has taken momentum from readers and many publishers, and vendors are providing e-books solutions to the readers in different methods on their own software platforms.

\section{E-BOOKS MARKET AND USAGE}

The use of internet in India has been significantly increasing, and use of digital information is boosting eBooks industry. The inventions and support of portable devices such as smart phones, e-book readers, tablets and others have made easier and compatible to access e-content. The statistics released by the Internet and Mobile Association of India and Indian Market Research Bureau IAMAI \& IMRB reveals that 375 million of users are accessed internet in the month of October 2015. This kind of internet usage habit among readers shows how people get attracted towards the use of e-books, but many have not accepted e-books as substitute for printed books. In Indian scenario, even still the libraries are struggling to attract users to the use of e-books platforms, but not successful in doing it. A survey was conducted by Amazon during the year 2012, in India, where $45 \%$ of readers prefer physical books, $20 \%$ of readers prefer e-books. Remaining $35 \%$ willing to switchover from printed to e-books only because of good discounts offered by the providers or publishers. In the recent development, 'Flipkart' a largest online store in India has withdrawn its e-books module launched in the year 2012 .

Flipkart has opinioned, 'The Indian book market is overwhelmingly dominated by physical books, and this is a market that is growing at a fast clip. Flipkart will continue to be a leading player in the overall books market in India. In an overall strategy for books, Flipkart does not see the eBooks service as a strategic fit and hence the decision of 
transitioning the eBooks service to Kobo' (http:/ / businessworld.in/article/Flipkart-Stops-Selling-EBooks/11-12-2015-89281/).

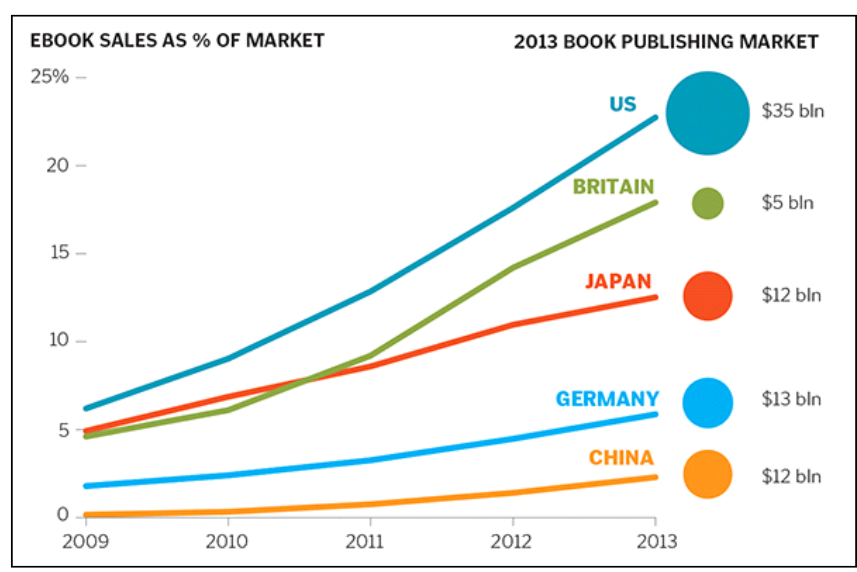

Top five countries that are using e-books

Source: Forbes India; retrieved on 01.06.2015 ihttp:/ / forbesindia.com/article/special/fine플 print-ebooks-yet-to-make-inroads-in-the-us / ธ39791/1].

F

In the e-book industry, publishers, educational institutes, libraries, aggregators, service providers and distributors are the major players.

은 Some of the major global e-book publishers or क् gaggregators are as follows (http:// 을 WWw.digitalbookworld.com/2014/ ebookòpublisher-power-rankings-top-publishers-of2014-so-far/):

- John Wiley

- Pearson

- McGraw-Hill

- Kensington Publishing Corp

- Cengage Learning

- Hachette

- HarperCollins

- Macmillan Publishers

- Simon \& Schuster

- Penguin Random House

- ACK Media
- Andrews UK Ltd.

- Tertiary Publishing

- Pigeon Labs

- Ciando

- Smashwords

- eBook Architects

- Dawson France

Like printed books, e-books also have got their own advantages and disadvantages.

\section{Advantages of E-books}

The advantages of e-books are as follows:

$\checkmark$ Easy transport/to carry anywhere with many books,

$\checkmark$ Saves space, minimal space and more books,

$\checkmark$ Multiple accessibility,

$\checkmark$ Simultaneous access,

$\checkmark$ Easy to search the content within the e-book,

$\checkmark$ Other added services like highlighting, notes making, use inbuilt or online dictionary, links to brief about new content the reader is not aware,

$\checkmark$ Eco-friendly - saves papers, saves trees,

$\checkmark$ E-books possible to access in audio format.

\section{Disadvantages of E-books}

The preservation of e-books is very difficult task because each e-book consists of several discrete elements such as content, formatting of work, file format, software needed to access it, operating system and hardware requirements. Some of the major disadvantages are as follows:

o Require devices to access/read,

o Require computer literacy,

o Internet facility and other Information Technology IT requirement,

o Electrical consumption,

o Licencing part, 
o More expensive,

o It can be hacked,

o Copyright security,

o All titles are not available in e-book format,

o No physical feel/appearance,

\section{E-Books Access Models}

Suppliers will have different kind of models to sell their e-books, based on the content, offer and agreement aspects, the libraries have to decide for further process of purchase. Many e-book models may confuse its use, advantages, disadvantages and others. The publishers usually sell e-books in three different models, they are as follows:

순. Perpetual model - pick and choose option.

部2. Subscription model - for particular period.

造3. Pay per view model - based on usage.

\section{-Perpetual Model}

เู่

Perpetual model is like selling of printed books. In this model, libraries may select the individual title and the distributor or publisher who sells the 난 踇To access the e-books, e-book collection Emanagement software is required, and this

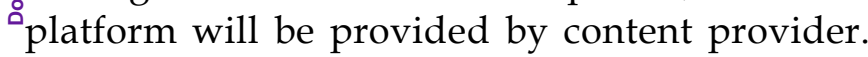
Again based on the licence terms or agreement during the acquisition of e-book, the book can be 'loaned out' through the software platform to library users. To avoid miss-use and hold the control over the content, publisher always use Digital Rights Management DRM and other technologies. Through this model, the publishers or vendors will assure that there won't be any additional charge on the e-book, if once they sell, it will be permanent asset for libraries or buyer. But in the real scenario, there is lack of transparency in licencing terms between publisher and libraries. To keep control on their content, publishers will set many restrictions in the agreement during the process of acquisition.

\section{Subscription Model}

In this model, e-book/s will be subscribed for predetermined period of time. The access of the content will be provided till the last date of subscription. Subscription will be terminated if the renewal is not made. Usually, the cost of the subscription model is lower than the perpetual model. The subscription cost may also depend on the users' registration.

\section{Pay-Per-Use Model}

This is the model where the content provider will raise the invoice to library based on the access of e-books. It may depend on number of users viewed the titles, pages and others.

\section{USER ACCESS TYPES}

\section{Single User Access}

'Single user access' means, a book can be accessible by single user at a time. E-book access will be given by the publisher through any e-book reader device. Similarly, it is possible to access on publisher platform by using username and password. Once the book installed on the device to the particular person for a particular period, it's not possible to migrate the e-book to any other device at any circumstances. Always access is configured to the buyer based on the device unique number called Media Access Control address (MAC address). If in case of device crash, buyer can request the new copy of e-book by giving declaration form to the provider mentioning the reasons. In such cases, publishers may consider the valid reasons, and based on the reality, reinstallation will be done; usually they provide new e-book, this option is given not exceeding three times during the purchase tenure, and this option may differs from publisher to publisher.

\section{Username and Password to Access}

In this case, a reader can get username and password to access the e-books based on the terms and condition of the provider. Publisher may provide the access as per below authentication: 
a) Internet Protocol IP control with username and password,

b) Anywhere access using username and password,

c) User authentication based on email configuration.

\section{Multiple User Access}

This is about simultaneous access to multiple users in multiple locations or said location at the same time without any interruption. Usually, publisher will provide this kind of access to the institutions on IP range or on offline platform on user server. In this system, authentication configured based on the IP or email address.

\section{LEGAL ASPECT OR COPYRIGHT ज़्रिRSTRICTION}

尔

In the digital information platform, publishers oalways look for an opportunity to restrict the Eaccess to the content of libraries that they have Fenjoyed in the print media. We may find that there are two fundamental characteristics that are flimiting libraries and its users in the e-book environment. The first characteristic is that e5books are leased to purchaser rather than sold. In othis way, the e-books are not covered by first sale 등 ঃ̆owner of the printed books can lend, rent, resell or give them to others without any restriction.

Second characteristic is that the libraries or end user may have to give up their rights while accessing e-books. For example, many publishers restrict inter library loan, transfer of content, using it for classroom purpose and others. Most of the licences and agreements are always favours towards publishers or vendors.

In case of print books as per First sale of doctrine, once the document is sold to a buyer, the buyer may re-sell or lend it to anyone. It means lawful ownership on purchased book, and it may be circulated among anyone as long as they require, whereas in case of e-books, publishers never provide such kind of rights to buyer, and they provide ownership only for a limited period.

\section{CONCLUSION}

In the digital age, the librarians have got major role in procuring and managing e-books. Especially publishers are yet to agree upon the best methods to provide and market e-books to libraries as per its requirement. In the process of e-books, acquisition librarians must proceed carefully and thoughtfully after the discussions with publishers on the part of licencing, content backup and legal aspects. Before getting into the agreement, it's required to go through carefully the terms and conditions that are mentioned by publishers. Librarians must not forget to include any terms and conditions that are required to safeguard their users or organisation. It's better to consult cyber legal expert during the agreement process to get clear understanding on the legal aspects. Regular library awareness events are warranted for users to educate do's and don'ts while accessing e-books models.

\section{REFERENCES}

Arshad K, 2015. Flipkart Stops Selling E-Books. Retrieved December 20, 2015, from [http://businessworld.in/ article/Flipkart-Stops-Selling-E-Books/11-12-2015$89281 /]$

Jeremy G, 2014. E-book Publisher Power Rankings: Top Publishers of 2014...So Far. Retrieved December 31, 2015, from [http://www.digitalbookworld.com/2014/ ebook-publisher-power-rankings-top-publishers-of2014-so-far/]

Manley L and Holley RP, 2012. History of the e-book: The changing face of books. Technical Services Quarterly, Vol. 29, No. 4, pp. 292-311.

Natalie R, 2015. Fine print: E-books yet to make inroads in the US. Retrieved November 30, 2015, from [http:// forbesindia.com/article/special/fine-print-ebooks-yetto-make-inroads-in-the-us/39791/1]

Widdersheim MM, 2015. E-book: Histories, trajectories, futures. First Monday, Vol. 20, No. 6. doi:10.5210/ fm.v20i6.5641 